\title{
Analysis of the correctly filling in the request form for Antimicrobials in an Oncology Reference Hospital in the State of Pará
}

\author{
Análise do preenchimento correto da ficha de solicitação de Antimicrobianos em um Hospital de \\ Referência Oncológica no Estado do Pará \\ Análisis del correcto llenado del formulario de solicitud de Antimicrobianos en un Hospital de \\ Referencia Oncológico del Estado do Pará
}

Received: 04/00/2021 | Reviewed: 05/00/2021 | Accept: 05/11/2021 | Published: 05/27/2021

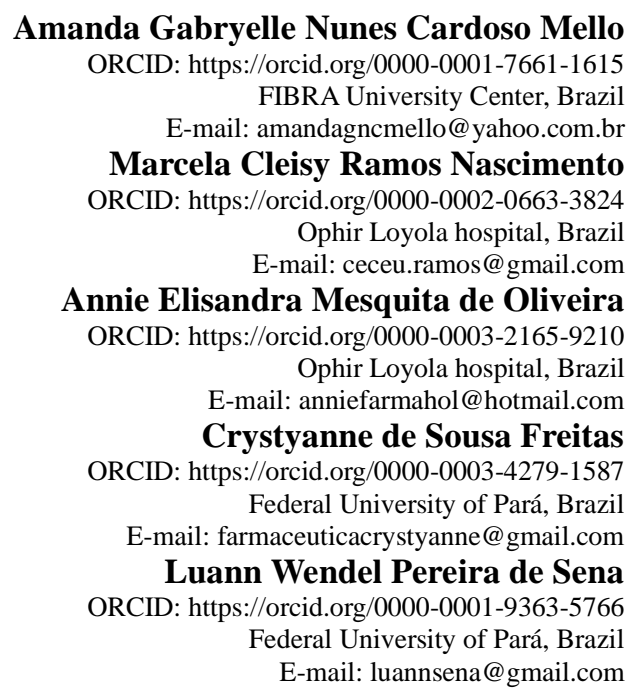

\begin{abstract}
Objective: Analyze the filling in the antimicrobial request form of the Intensive Care Unit in an oncology reference hospital in the state of Pará. Methods: This was a quantitative and retrospective study by collecting data from the restricted use antimicrobials request form, developed in the Intensive Care Unit of Hospital Ophir Loyola. Forms analyzed were from August to December 2018 in the file of the Hospital Infection Control Committee. Data obtained were organized in a database in Microsoft Excel ${ }^{\circledR}$ software, for descriptive statistical application, and the results were categorized and presented in a box and tables. Results: Of the 469 forms analyzed, 125 belonged to the month of August (27\%), 96 (20\%) September, 79 (17\%) October, 96 (20\%) November (20\%) and $73(16 \%)$ December. Meropenem was the most prescribed medication in the first three months $(16 \%, 21.90 \%$ and $20.30 \%)$, in November, vancomycin was the most dispensed (11.5\%) and, in December, piperacillin-tazobactam (tazocin - 20.5\%). Regarding non-conformities, there is no form with the item "pharmaceutical form". There were missing information on indication of use, data on the isolated infectious agent and omission of information on "progress of the requested microbiological study". The indication for use was comprised between empirical and specific therapy. Conclusion: Thus, it is necessary to adjust the antimicrobial request form, inserting complementary data for greater patient safety and better prescription, promoting their rational use.
\end{abstract}

Keywords: Antimicrobials; Intensive care unit; Hospital infection control committee; Rational use of medication.

\section{Resumo}

Objetivo: Analisar o preenchimento do formulário de solicitação de antimicrobianos da Unidade de Terapia Intensiva de um Hospital de referência oncológica do Estado no Pará. Métodos: Trata-se de um estudo quantitativo e retrospectivo por levantamento de dados da ficha de solicitação de antimicrobianos de uso restrito, desenvolvido na Unidade de Terapia Intensiva do Hospital Ophir Loyola. As fichas analisadas foram dos meses de agosto a dezembro de 2018 do arquivo da Comissão de Controle de Infecção Hospitalar. Os dados obtidos foram organizados em um banco de dados no software Microsoft Excel®, para aplicação estatística descritiva, sendo que os resultados foram categorizados e apresentados em quadro e tabelas. Resultados: Das 469 fichas analisadas, 125 pertenciam ao mês agosto (27\%), 96 (20\%) setembro, 79 (17\%) outubro, 96 (20\%) novembro (20\%) e 73 (16\%) dezembro. O meropenem foi o medicamento mais prescrito nos três primeiros meses $(16 \%, 21,90 \%$ e $20,30 \%)$, já em novembro, a vancomicina 
foi o mais dispensado $(11,5 \%)$ e, em dezembro, o piperacilina-tazobactam (tazocin - 20,5\%). Em relação às inconformidades, observou-se que não há em nenhuma ficha com o item "forma farmacêutica". E notaram-se ausências de informação indicação de uso, dados sobre o agente infecioso isolado e omissão de informações sobre "andamento do estudo microbiológico solicitado". Já a indicação de uso ficou compreendida entre terapia empírica e específica. Conclusão: Assim, faz-se necessário o ajuste na ficha de solicitação de antimicrobiano, inserindo dados complementares para maior segurança do paciente e melhor prescrição, promovendo o uso racional destes.

Palavras-chave: Antimicrobianos; Unidade de terapia intensiva; Comissão de controle de infecção hospitalar; Uso racional de medicamento.

\begin{abstract}
Resumen
Objetivo: Analizar la cumplimentación del formulario de solicitud de antimicrobianos de la Unidad de Cuidados Intensivos de un hospital estatal de referencia en oncología en Pará.Métodos: Se trata de un estudio cuantitativo y retrospectivo mediante la recolección de datos del formulario de solicitud de antimicrobianos de uso restringido, desarrollado en la Unidad de Cuidados Intensivos del Hospital Ophir Loyola. Los archivos analizados estuvieron de agosto a diciembre de 2018 en el archivo de la Comisión de Control de Infecciones Hospitalarias. Los datos obtenidos fueron organizados en una base de datos utilizando el software Microsoft Excel®, para aplicación estadística descriptiva, y los resultados fueron categorizados y presentados en tabla y tablas. Resultados: De los 469 registros analizados, 125 pertenecían al mes agosto (27\%), 96 (20\%) septiembre, 79 (17\%) octubre, $96(20 \%)$ noviembre (20\%) y $73(16 \%)$ diciembre . El meropenem fue el medicamento más prescrito en los primeros tres meses $(16 \%, 21,90 \%$ y $20,30 \%)$, en noviembre la vancomicina fue la más dispensada $(11,5 \%)$ y en diciembre piperacilina-tazobactam (tazocina - 20,5\%). En cuanto a las no conformidades, se observó que no existe ningún formulario con el ítem "forma farmacéutica" de ninguna forma. Y hubo ausencia de información sobre indicación de uso, datos sobre el agente infeccioso aislado y omisión de información sobre "avance del estudio microbiológico solicitado". La indicación de uso, en cambio, se comprendió entre terapia empírica y específica. Conclusión: Por ello, es necesario adecuar el formulario de solicitud de antimicrobianos, insertando datos complementarios para una mayor seguridad del paciente y una mejor prescripción, promoviendo el uso racional de estos.
\end{abstract}

Palabras clave: Antimicrobianos; Unidad de terapia intensiva; Comisión de control de infecciones hospitalarias; Uso racional de medicamentos.

\title{
1. Introduction
}

Antimicrobials (ATs) is a comprehensive term used for the class of drugs of natural or synthetic origin that has the function of inhibiting or destroying fungi, bacteria and protozoa (Guimarães, Momesso \& Pupo, 2010). They are drugs that aim to improve the quality and life expectancy of people, and in the hospital, they are part of one of the most prescribed therapeutic groups. However, they are not necessarily used in a rational way, which makes their indiscriminate use one of the major public health problems (Mourelle et al., 2015; Rondón et al., 2017).

According to Sampaio et al., (2018), antibiotics are substances capable of preventing reproduction or causing the destruction of bacteria. And when reaching that goal, we can say that the microorganism is sensitive to the drug. But when it is necessary high levels of antimicrobials and their effects are ineffective, this microorganism is resistant.

Bacterial resistance is very difficult to treat, as it helps in the proliferation of bacteria and the patient's stay in the area. Therefore, drugs should be rationally prescribed, not only in diagnoses on epidemiological data of certain etiologic agents, but in a concrete diagnosis (Fiol et al., 2010).

In the hospital, nosocomial infection is a public health problem, becoming a concern for multiprofessional teams and responsible bodies, since it is related to the high rate of morbidity and mortality, the increase in the time spent in this place and the high costs for health facilities (Oliveira, Assis \& Barboni, 2010).

According to the National Health Surveillance Agency (Anvisa, 2012), bacterial resistance is considered by the World Health Organization (WHO) to be a worldwide public health problem, which makes recommendations on maintaining surveillance and promoting the use of antimicrobials, application of rules to order to prevent the sale of antimicrobials without prescription and strict compliance with infection prevention measures, such as washing hands, especially in health services.

The Ministry of Health (MS), through Ordinance 2616 of May 12, 1998, reports that Hospital Infection (HI) is obtained after the patient admission to the hospital and is revealed during the period of hospitalization or after discharge, once 
it is linked to hospitalization or hospital protocols. To this end, it is mandatory for hospitals in the country to maintain Hospital Infection Control Programs, which constitute a set of actions developed deliberately and systematically, with a view to reducing the maximum possible incidence and severity of hospital infections (Ribeiro et al., 2016).

Therefore, filling in the antimicrobial request form is the first step in the use of this category of drugs in the hospital environment and its adequate filling is of great importance in the pharmacotherapeutic analysis by the pharmacist who dispenses it and in the clinical analysis by the Hospital Infection Control Committee (HICC), which can assist in the development of new practices that guarantee the adequate and rational use of medications, thus increasing patient safety (Faria, Pessalacia \& Silva, 2016).

Thus, it is necessary to carry out a pharmacoepidemiological assessment of the quality of filling out antimicrobial records in a hospital service of the Intensive Care Unit (ICU), of a large hospital, with the goal of evaluating form filling, proposing changes and strategies that promote rational use of antimicrobials in the institution.

\section{Methodology}

This is a quantitative and retrospective research through data collection from the request form for antimicrobials of restricted therapeutic use, developed at the ICU of the Hospital Ophir Loyola (HOL), which has units for high-complexity intensive care and treatments for the various specialties, with a multidisciplinary team for 24 hours distributed between morning (6 am), afternoon (6 am) and night (12 pm), with 30 beds, divided into clinical, surgical and neurosurgical ICUs.

The forms analyzed were from all patients treated at the ICU of the hospital from August to December 2018. However, illegible forms were excluded, with the presence of erasures and/or any characteristic that made it impossible to obtain data.

Data were collected by accessing the HICC file, where they were stored, and for the reading and presence of relevant data, a collection tool was used (figure 1), which aimed to standardize and avoid possible errors in the process of obtaining the information.

Figure 1 - Request form for antimicrobials.

\section{Form for evaluation of the antimicrobial form of the Ophir Loylola Hospital}

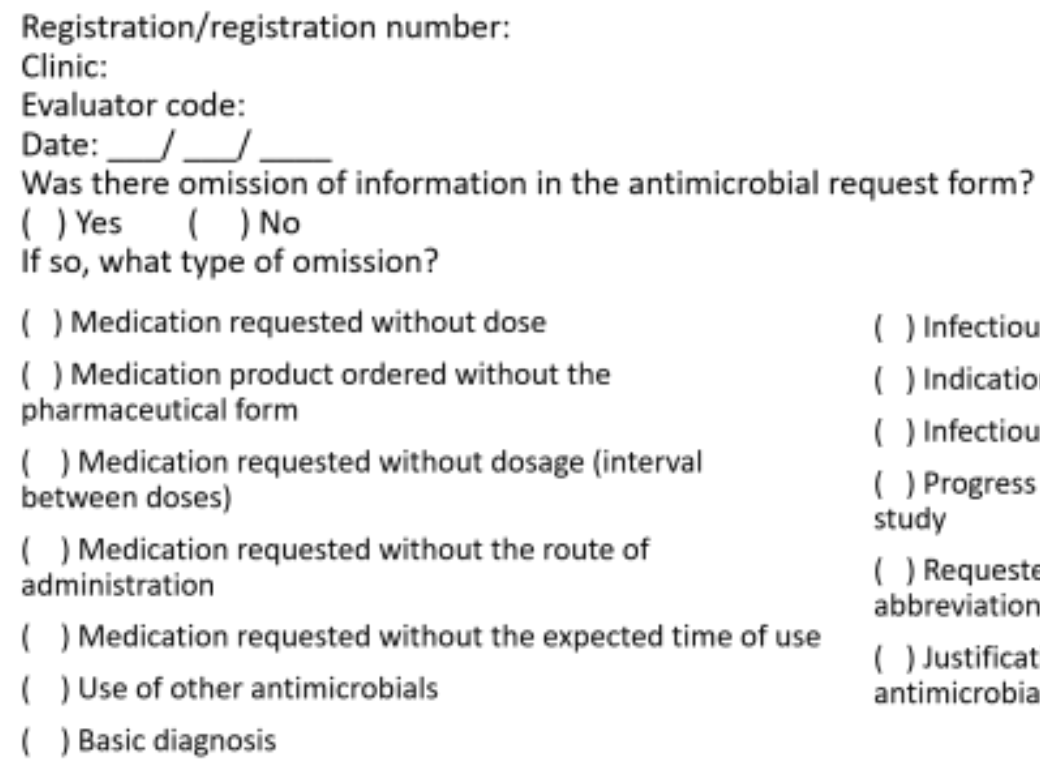

\section{( ) Infectious diagnosis}

( ) Indication of use

( ) Infectious agent isolated

( ) Progress of the requested microbiological study

( ) Requested drug, using contraindicated abbreviation

( ) Justification for choosing the requested antimicrobial 
This type of investigation approved by the HOL Ethics Committee under the CAAE number: 11069019.3.3001.5550, opinion (3.420.804/2019). Data obtained were organized in a database in Microsoft Excel ${ }^{\circledR}$ software for descriptive statistics, and the results were categorized and presented in a box and percentage tables.

\section{Results}

From the inclusion criteria adopted, 469 antimicrobial request forms from August to December 2018 were analyzed, 125 in August (27\%), 96 in September (20\%), 79 in October (17\%), 96 in November (20\%) and 73 in December (16\%; Graph $1)$.

Graph 1 - Antimicrobial request forms along the study period, in percentage.

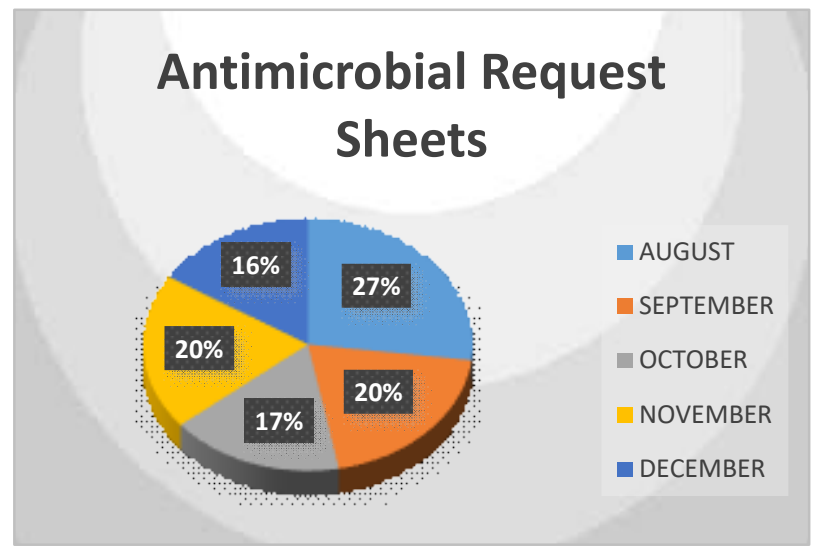

Source: Authors (2021).

Meropenem was the most prescribed medication in the first three months of the study (16\% in August, $21.90 \%$ in September and $20.30 \%$ in October). In November, stood out vancomycin (11.50\%) and, in December, Piperacillin-tazobactam (tazocin - 20.50\%) (Graph 2).

Graph 2 - The most prescribed drugs in the ICU of an oncology reference hospital in the state of Pará from August to December 2018.

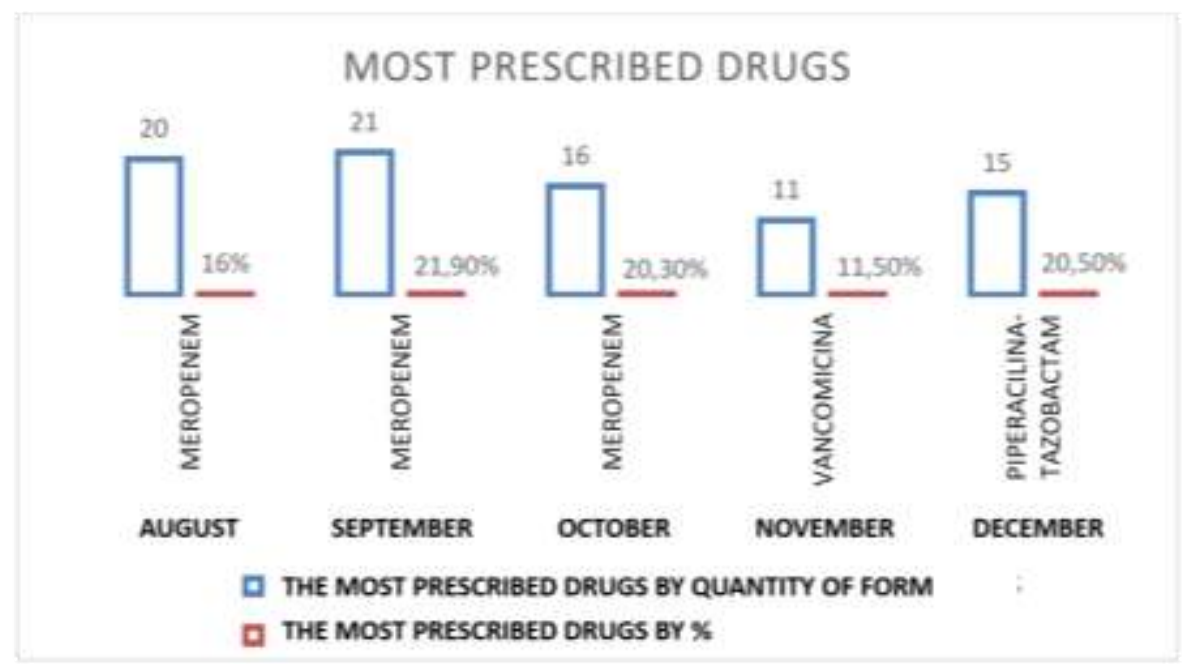

Source: Authors (2021). 
Regarding the "non-compliance with filling out", there was no item "pharmaceutical form" in the form, considered $100 \%$ omission (Table 1). In addition, there were missing information on indication of use, data on the isolated infectious agent throughout the study period, the last variable is related to the indication of use when therapy is specific. The occurrence of indication of use, however, was comprised between empirical therapy and specific therapy (Graph 3).

The variable with the greatest omission of data information was the "progress of the requested microbiological study", with the most absent months being August (20.8\%), September (23.96\%), October (22.78\%) and November (22.92\%), as listed in Table 1.

Table 1 - Omission of data from antimicrobial request forms in percentage (\%).

\begin{tabular}{|c|c|c|c|c|c|}
\hline & AUG & SEP & OCT & NOV & DEC \\
\hline VARIABLES & $\%$ & $\%$ & $\%$ & $\%$ & $\%$ \\
\hline DRUG REQUESTED WITHOUT DOSAGE & 1.6 & - & - & - & 1.37 \\
\hline DRUG REQUESTED WITHOUT PHARMACEUTICAL FORM & 100 & 100 & 100 & 100 & 100 \\
\hline DRUG REQUESTED WITHOUT POSOLOGY (INTERVAL BETWEEN & - & - & - & - & - \\
\hline \multicolumn{6}{|l|}{ DOSES) } \\
\hline DRUG REQUESTED WITHOUT THE ROUTE OF ADMINISTRATION & - & - & 2.53 & 1.04 & 1.37 \\
\hline MEDICINE REQUESTED WITHOUT THE EXPECTED TIME OF USE & 0.8 & 2.8 & 1.27 & - & 1.37 \\
\hline USE OF OTHER ANTIMICROBIALS & 4 & - & - & 2.08 & 1.37 \\
\hline BASE DIAGNOSIS & 0.8 & - & - & - & 2.74 \\
\hline INFECTIOUS DIAGNOSIS & 0.8 & - & 2.53 & - & 8.22 \\
\hline INDICATION OF USE & 4.8 & 5.21 & 5.06 & 4.17 & 5.48 \\
\hline ISOLATED INFECTIOUS AGENT & 4.8 & 5.21 & 3.8 & 3.13 & 4.11 \\
\hline PROGRESS OF THE REQUESTED MICROBIOLOGICAL STUDY & 20.8 & 23.96 & 22.78 & 22.92 & 10.96 \\
\hline DRUG REQUESTED USING CONTRAINDICATED ABBREVIATION & 2.4 & 2.08 & - & - & - \\
\hline JUSTIFICATION FOR CHOOSING THE REQUESTED ANTIMICROBIAL & - & 3.13 & - & - & 2.74 \\
\hline
\end{tabular}


Graph 3 - Indication of the use of antimicrobials, in percentage, of a referral hospital for cancer in the State of Pará.

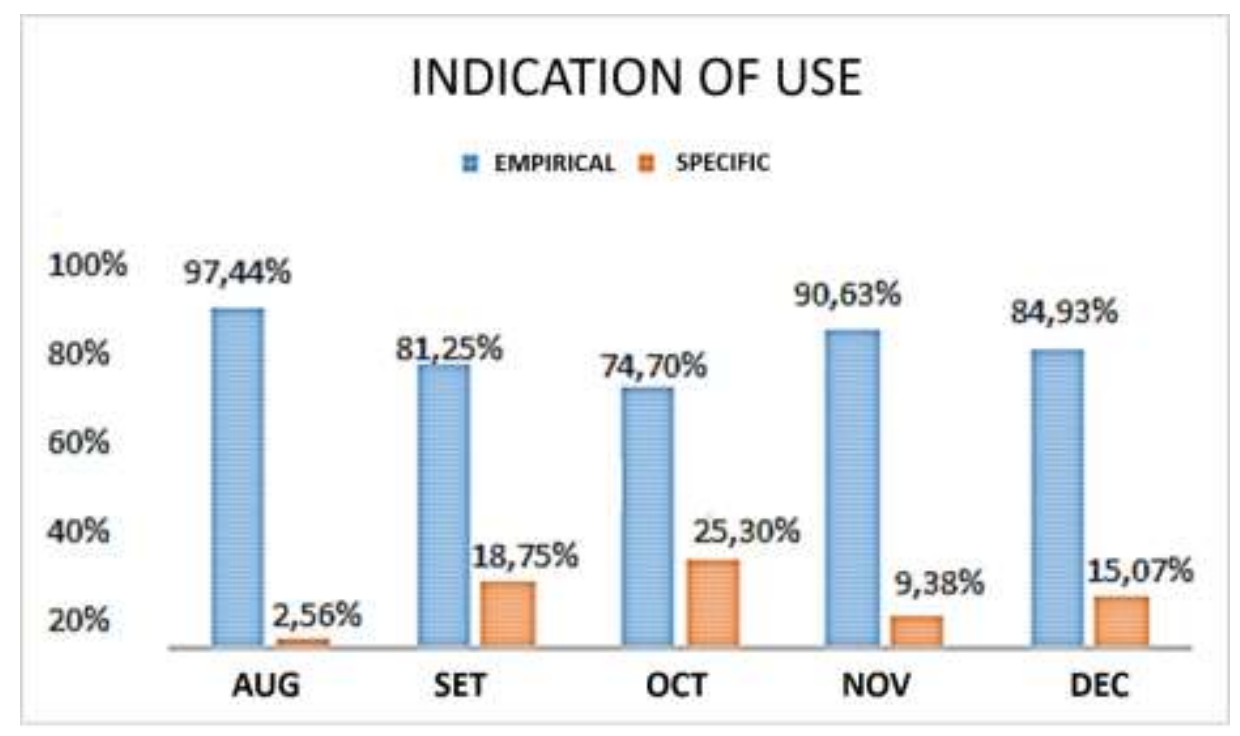

Source: Authors (2021).

\section{Discussion}

Meropenem was the most prescribed medication in the first three months of the collection period. It belongs to the class of carbapenems, being considered the antimicrobial with the widest spectrum of action used in the treatment of severe respiratory, intra-abdominal infections, septicemia, urinary tract and gynecological infections, among others (Palacios et al., 2015). Similar data were verified by Alvin et al., (2015) and Souza et al., (2017), who observed that this antimicrobial was the most prescribed to patients found in 43 ICUs in Latin America, noting that the prescription was linked to empirical use in the occurrence of serious infections, maintaining even with the result of culture, with the objective of maintaining safety and a broad spectrum of coverage against microorganisms and/or only to use.

However, Neves \& Colet (2015), in an adult ICU of a Hospital in Rio Grande do Sul, reported a higher prevalence of prescriptions for vancomycin. However, there was an increase in the resistance of enterococci due to the widespread use of this medicine. Teixeira (2014) observed that polymyxin B (23.7\%) was the most prescribed antimicrobial, which is active against $P$. aeruginosa, including strains resistant to carbapenems.

Furthermore, Oliveira et al., (2015) verified a high prescription of vancomycin (69.4\%), emphasizing that there was no great difference between the groups analyzed for any class of antimicrobials empirically prescribed. Nevertheless, Tavares et al., (2015), in a Teaching Hospital in Recife (state of Pernambuco), detected differences between the prescribed classes, in which the most prevalent in the ICU were piperacillin-tazobactam (Tazocin - 19.4\%), followed by meropenem (9.7\%), justifying that the use of meropenem was linked to the lack of response to Tazocin, since only one carbapenem should be used in infections resistant to all other beta-lactams.

Therefore, although patients admitted to the ICU represent only 5\% to $10 \%$ of the total number of hospitalized patients, the risk of developing infections with multidrug-resistant bacteria is 10 times greater in relation to other sectors and, depending on the profile of the user, the rate of mortality can reach $80 \%$ hospitalization (Perna et al., 2017).

One of the reasons that can contribute to the emergence of resistant infections in hospitals is the presentation of the drug, that is, the pharmaceutical form, since, depending on the severity of the patients who are in the ICU, there is a need to reach specific concentrations of the medication that provides an immediate pharmacological effect (Santos et al., 2016). In 
addition, the absence of this topic in the request form may result in doubts in the dispensing of the medication, and, consequently, the impairment of the therapy (Nascimento \& Magalhães, 2013).

Another factor contributing to the emergence of microorganism resistance is the correct targeting to specific pathogenic strains through the diagnosis of microbiological exams to identify them. It was observed in this study that, in all collection months, it presented absence of "information on indication of use" and lack of data about the isolated infectious agent. For Silva (2012), the specific treatment should be when the choice of the drug is guided by a microbiological efficacy test for microorganisms isolated from the patient. But there are cases that it is necessary to start the treatment before laboratory diagnosis, called empirical therapy, which is justified in cases of serious infections, but the collection of samples for the culture must be done in all cases for confirmation or redirection of antimicrobial treatment.

Thus, Rodrigues et al., (2013) noted that out of the 24 patients admitted to the ICU of a Public Hospital in Teresina (state of Piauí), $12.5 \%$ had no culture or exams, and $20.8 \%$ had missing data on the HICC form. In addition, they observed the beginning of the empirical treatment in $66.7 \%$ patients who had biological material collected for microbiological exams, even without the identification of the pathogens, as they were still waiting for the microbiological diagnosis to be released, which implies compromising the rational use of these drugs.

The research carried out by Faria et al., (2016) shows that the empirical use of antimicrobials and the non-request for culture with antibiogram are risk situations, when broad spectrum drugs are used empirically, and only $18.5 \%$ of all patients treated with at least one drug in this study had undergone the culture test with antibiogram. With a similar observation, Reis et al., (2013) reported the increase in the emergence of resistant bacteria from the unnecessary use of broad-spectrum AT's.

Over the years, etiological agents related to nosocomial infection undergo constant changes and it is necessary to have perfect knowledge about the hospital bacterial microbiota to seek more effective measures in the control of nosocomial infections (Marco, Denti \& Manfredini, 2014).

Therefore, Mota et al. (24) report that the ICU is an environment conducive to pathogenic agents, with $30 \%$ hospital infections occurring in this location, since there are factors that favor the proliferation of microorganisms, such as the diversity and dissemination of agents due to the flow of patients undergoing surgery, the long hospital stay, the underlying disease, use of urinary and venous catheters, mechanical ventilation, immune status, age and use of immunosuppressive medications, which facilitates the susceptibility to acquire such infections.

However, in most Hospital Infection Control Services (SCIH), it is standard to request culture tests to identify microorganisms causing hospital infections, which can be a useful instrument for the intervention of that service in antimicrobial treatments (Faria, Pessalacia \& Silva, 2016).

In fact, it has been observed in some studies (Oliveira, De Paula \& Rocha, 2015; Santos et al., 2016) the empirical use of antimicrobials, making it necessary to adjust the "therapeutic use in the antimicrobial request form", inserting complementary data for greater patient safety and better prescription, in order to promote the rational use of antimicrobials.

Another data of great relevance is to insert the "weight" and "creatinine dosage" in the form, since the high consumption of antimicrobials contributes to renal complications, which is linked to the choice of the drug and the dose considered. For this, it would use the calculation of the glomerular filtration rate using the Cockcroft-Gault Formula, which uses values of plasma creatinine, weight and age of the patient in the first $48 \mathrm{~h}$ of prescription after the exam. Thus, if there is a need to change the dose of the prescribed antimicrobial, this 48-hour time would be sufficient (Cotrim et al., 2013).

It is also necessary to reduce the use of antimicrobials, from 10 to 7 days, in order to contribute to the rational use and, consequently, to reduce costs with the use of these drugs, as well as it is suggested the removal of the term "restricted" from 
the title of the form because, according to the Medication Standardization Guide of HOL, antimicrobials for therapeutic use and restricted use with high cost were classified with the need for prior approval by the HICC.

\section{Conclusion}

Thus, this study demonstrates that resistance to antimicrobials is associated with their clinical use, especially in hospitals where use is greater. However, there are several factors that lead to misuse that directly impacts the treatment quality. Therefore, there is a need for effective interventions, such as the control of antimicrobials and the control and prevention of Healthcare-Related Infections (HAI), in the hospital environment to minimize this resistance, since, currently, the rational use of these drugs is considered one of the main challenges faced in the treatment of infectious diseases in a hospital environment.

\section{Acknowledgments}

The authors would like to thank Ophir Loyola Hospital for collaborating with the research involved.

\section{References}

Alvim, M. M.; Silva, L. A.; Leite, I. C. G. \& Silvério, M. S (2015). Eventos adversos por interações medicamentosas potenciais em unidade de terapia intensiva de um hospital de ensino. Rev Bras Ter Intensiva., 27 (4), 353-359.

Anvisa. (2012). Resolução da Diretoria Colegiada - RDC no 20, de 05 de maio de 2012. Dispõe sobre o controle de medicamentos à base de substâncias classificadas como antimicrobianos, de uso sob prescrição, isoladas ou em associação. Diário Oficial da União de 09 de maio de 2012 , (seção 1): 39-40.

Cotrim, E. R.; Costa, J. M.; Silva, M. D. G. \& Mourão, A. O. M. (2013). Análise de prescrições de antimicrobianos para pacientes com acometimento renal Rev. Bras. Farm. Hosp. Serv. Saúde, 4 (2), 19-23.

Faria, T. V.; Pessalacia, J. D. R. \& Silva, E. S (2016). Fatores de risco no uso de antimicrobianos em uma instituição hospitalar: reflexões bioéticas. Acta Bioethica, 22 (2), 321-329.

Fiol, F. D. S.; Lopes, L. C.; Toledo, M. I. \& Barberato, S (2010). Perfil de prescrições e uso de antibióticos em infecções comunitárias. Rev. Soc. Bras. Med. Trop., 43 (1), 68-72.

Guimarães, D. O.; Momesso, L. S. \& Pupo, M. T. (2010). Antibióticos: Importância Terapêutica e Perspectivas para a descoberta e desenvolvimento de novos agentes. Quim. Nova, 33 (3), 667-679.

Marco, S. L.; Denti, I. A. \& Manfredini, C. S. (2014). Prevalência de infecções em uma unidade de terapia intensiva pediátrica e neonatal. PERSPECTIVA, 38, 73-81.

Mota, F. S.; Oliveira, H. A.; Souto, R. C. F. C (2018). Perfil e prevalência de resistência aos antimicrobianos de bactérias Gram-negativas isoladas de pacientes de uma unidade de terapia intensiva. RBAC., 50 (3), 270-277.

Mourelle, J. A. F.; Barrios, M. A. C.; Aaguilera, A. F. L.; Núnez, D. M. \& Oorta, I. A (2015). Reacciones adversas por antimicrobianos em ninos de Cuba. Rev. Cubana Med. Gen Intergr., 31 (2), 205-216.

Nascimento, P. S. \& Magalhães, I. R. S. (2013). Análise da prescrição de antimicrobianos dispensados em uma rede de drogarias. Rev. Bras. Farm. Serv Saúde, 94 (3): 211

Neves, C. \& Colet, C (2015). Perfil de uso de antimicrobianos e suas interações medicamentosas em uma uti adulto do Rio Grande do Sul. Rev Epidemiol Control Infect., 5 (2), 65-71.

Oliveira, L. C. F.; Assis, M. M. A. \& Barboni, A. R (2010). Assistência Farmacêutica no Sistema Único de Saúde: da Política Nacional de Medicamentos à Atenção Básica à Saúde. Ciênc. Saúde Colet., 15 (Supl. 3), 3561-3567.

Oliveira, A. C.; De Paula, A. O. \& Rocha, R. F (2015). Custos com antimicrobianos no tratamento de pacientes com infecção. Av Enferm., 33 (3), $352-361$.

Palacios, J. A.; Ojeda, S. B.; Gonzalez, V. O. \& Moreno, M. M (2015). Comparación de la actividad antimicrobiana de meropenem genérico y meropenem innovador por la técnica de micro dilución en cepas resistentes. Rev. cuba farm., 49 (4), 651-663.

Perna, T. D. G. S.; Puiatti, M. A.; Perna, D. H.; Pereira, N. M. M.; Couri, M. G. \& Ferreira, C. M. D (2015). Prevalência de infecção hospitalar pela bactéria do gênero klebsiella em uma Unidade de Terapia Intensiva. Rev Soc Bras Clin Med., 13 (2), 119-123.

Reis, H. P. L. C.; Vieira, J. B. M.; Sartori, D.P.; Fonseca, D. P.; Viana, D.B. \& Cunha, J.M. (2013). Avaliação da resistência microbiana em hospitais privados de Fortaleza-Ceará. Rev Bras Farm., 94 (1), 83-87. 
Research, Society and Development, v. 10, n. 6, e19410615608, 2021

(CC BY 4.0) | ISSN 2525-3409 | DOI: http://dx.doi.org/10.33448/rsd-v10i6.15608

Ribeiro, A. E. O; Lima, M.S.; Castro, R. A.; Ribeiro, T. L. S. \& Santos, C. R. B (2016). Infecções hospitalares: aspectos relevantes e a atuação dos profissionais de enfermagem no controle de infecções. Mostra Interdisciplinar do curso de Enfermagem, 2 (01).

Rodrigues, A. M. X.; Paz, I. F. R. \& Freitas, R. M (2013). Problemas Relacionados com antimicrobianos em UTI em um Hospital Público de Teresina. Revista Multiprofissional em Saúde do Hospital São Marcos, v I (01), 40-49.

Rondón, Y. R.; Prosper, C. P.; Matamoros, O. B.; Moro, A. Z. \& Sánchez, V. Z. R (2017). Prescripción de antimicrobianos y su relación con la resistencia bacteriana en un hospital general municipal. MEDISAN, 21 (5), 534-539.

Sampaio, P. S.; Sancho, L. G. \& Lago, R. F. (2018). Implementação da nova regulamentação para prescrição e dispensação de antimicrobianos: possibilidades e desafios. Cad. Saúde Colet., 26 (1), 15-22.

Santos, R.G. et al. (2016). Prescrições de antimicrobianos de uso restrito de pacientes internados em um hospital de ensino. Rev. Bras. Farm. Hosp., 7 (1), 8 12 .

Silva, E. R. M. (2012). Análise do perfil das prescrições de antimicrobianos na clínica médica de um hospital público do Pará. Rev Bras Farm Hosp Serv Saúde., 3 (2), 15-19.

Souza, F. C.; Baroni, M. M. F.; Roese, F. M (2017). Perfil de utilização de antimicrobianos na unidade de terapia intensiva de um hospital público. Rev. Bras. Farm. Hosp. Serv. Saúde, 8 (4), 37-44.

Tavares, C. A.; Veras, M. C. B.; Silva, A. C. R.; Araújo, S. E. S. \& Lima, M.F.S (2015). Avaliação da prescrição de antimicrobianos para infecção relacionada à assistência à saúde em um Hospital Escola de Recife - PE. Rev Epidemiol Control Infect., 5 (3), 123-130.

Teixeira, M. O (2014). Estudo de prescrições de antimicrobianos na unidade de terapia intensiva de um hospital terciário do Distrito Federal. Monografia (Bacharelado em Farmácia). Universidade de Brasília, Ceilândia-DF, 58 p. 